\title{
STABILIZING CAPITAL FLOWS TO DEVELOPING COUNTRIES
}

\author{
Dr Stephany Griffith-Jones \\ Institute of Development Studies \\ Sussex University \\ Brighton BN1 9RE \\ England
}

Fax: $44(1273) 621202$

E-Mail: s.griffith-jones@ids.ac.uk

Paper prepared for Conference on the East Asian crisis, held at the Institute of Development Studies, Brighton on 13/14 July 1998. This paper draws on work undertaken for the Expert Group Meeting of the Commonwealth Secretariat in London on 15 -17 June 1998. I appreciate the financial support of the Commonwealth Secretariat and the valuable suggestions of Aziz Ali Mohammed and Rumman Faruqi. I also thank Jenny Kimmis for her research assistance. 


\section{Introduction}

The deep integration of developing countries into the global economy has many advantages and positive effects.

In particular, capital flows to developing countries have clear and important benefits. The benefits are especially clear for foreign direct investment, which is not only more stable, but also brings technological know-how and access to markets. Other external flows also have important positive micro-economic effects, such as lowering the cost of capital for creditworthy firms. At a macro-economic level, foreign capital flows can complement domestic savings, leading to higher investment and growth; this latter positive macro-economic effect is very valuable for low-savings economies, but may be less clear for high-savings economies like those of East Asia.

However, large surges of short-term and potentially reversible capital flows to developing countries can also have very negative effects. Firstly, these surges pose complex policy dilemmas for macro-economic management, as they can initially push key macro-economic variables, such as exchange rates and prices of assets like property and shares, away from what could be considered their long-term equilibrium. Secondly, and more important, these flows pose the risk of very sharp reversals. These reversals - particularly if they lead to currency and financial crises - can result in very serious losses of output, investment and employment, as well as increases in poverty.

In the case of the Asian crisis, the reversal of private capital flows has been really dramatic. According to figures from the Institute of International Finance, the five East Asian countries hardest hit by the crisis (South Korea, Indonesia, Malaysia, Thailand and the Philippines) experienced in a single year a turnaround of US\$105 billion, reaching more than 10 per cent of the combined GDP of these economies; the shift was from an inflow of capital of + US\$93 billion in 
1996 to an estimated outflow of US\$12 billion in 1997 (see Table 1). Most of this dramatic swing originated from commercial bank lending (which fell by US\$76.8 billion), whilst foreign direct investment remained constant (see again Table 1).

This massive and sudden withdrawal of capital flows in itself caused a dramatic reduction in absorption, as well as currency crises. In Asia, violent devaluation and large increases in interest rates implied that the currency crises interacted with banking crises, which led to contraction of bank lending. It is interesting that usually in developing countries (with Mexico in 1994-95 providing another good example), currency crises spill over into domestic financial crises and vice-versa, whereas this does not happen very often in developed countries (Akyuz, 1998).

\section{TABLE 1}

\section{Five Asian Economies External Financing (US\$billion)}

$1996 \quad 1997 \quad$ Change between
1996 and 1997

$\begin{array}{lrrr}\text { External financing, net } & 92.8 & 15.2 & -77.6 \\ \text { Private flows, net } & 93.0 & -12.1 & -105.1 \\ & & & -23.6 \\ \text { Equity investment } & 19.1 & -4.5 & +0.2 \\ \quad \text { Direct equity } & 7.0 & 7.2 & -23.7 \\ \quad \text { Portfolio equity } & 12.1 & -11.6 & -81.6 \\ \quad & & -7.6 & -76.8 \\ \text { Private creditors } & 74.0 & -21.3 & -4.7 \\ \quad \text { Commercial banks } & 55.5 & 13.7 & +27.4 \\ \quad \text { Non-bank private creditors } & 18.4 & & \end{array}$

Source: Institute of International Finance "Capital Flows to Emerging Economies". January 29, 1998 Washington D.C. 
The combination of the reversal of capital flows, currency and domestic financial crises led in East Asia to a very severe economic crisis in countries that had been growing extremely rapidly for a very long period. According to the International Monetary Fund's April World Economic Outlook (1998), growth of GDP in the Asian NIC's - Hong Kong, Singapore, South Korea and Taiwan - will fall by 4.2 per cent in 1998 to a mere 1.8 per cent; for Thailand, Malaysia, Indonesia and the Philippines the decline is far more dramatic, as their combined GDP will fall by 8.1 percentage points, to -2.7 per cent.

In Mexico, Gross Domestic Product fell by almost 7 per cent in 1995 in the wake of the peso crisis, with investment and consumption falling over 15 per cent during that year.

Within present arrangements, the volatility and reversibility of some categories of capital flows and their very negative effects implies that the costs of these flows to countries' development are seen as higher than their benefits, at least during important periods of time.

As a consequence, there is growing consensus that important changes need to be made in the international monetary system as a whole - and in recipient country policies - to avoid costly crises, as well as to manage them better if they do occur. Important economic authorities like Alan Greenspan, Chairman of the U.S. Federal Reserve, (Financial Times, 28 Feb 1998) and Joseph Stiglitz, Chief Economist of the World Bank (Stiglitz, 1998 a and b) as well as several important analysts, have called for such changes.

It seems urgent to:

a) identify the possible changes required to achieve this result,

b) evaluate the potential economic effects of such changes and

c) define institutional developments that would be required to implement those changes. 
This chapter attempts to contribute elements to the on-going important debate on this issue. Section II will explore further the causes of the East Asian crisis, focusing on those more relevant to the central issues of this chapter. Section III examines measures for crisis prevention. More emphasis will be placed on international measures, like better surveillance by the IMF and better regulation of capital by source countries and internationally; however, some of the market based policies that may need to be taken by recipient countries to discourage excessive surges of shortterm capital flows is also evaluated. Section IV examines the measures to better manage international crises if they do occur, including the expanded role of the IMF as a lender of last resort and better debt work-out mechanisms. Section V concludes and summarises.

\section{Causes of the Asian Crisis}

A large literature is emerging emphasising from different perspectives the domestic causes of the Asian crisis, for example Boorman (1998), Corsetti, Pesenti and Roubini (1998), IMF (1997), Radelet and Sachs (1998) and Wade and Veneroso (1998). It is beyond the scope of this chapter to examine the varying domestic causes of the crisis. Three key points are, however, worth stressing (Stiglitz, 1997). Firstly, the current account deficits in East Asia reflected private sector deficits. Secondly, the Asian crisis was a consequence of overinvestment (some or much of it misallocated) and not of overconsumption. Thirdly, the most important cause of the crisis was a sharp deterioration in confidence, not of macro-economic fundamentals, which were mostly extremely strong.

Indeed, what seems most disturbing about the Asian crisis is that it happened to countries that had been so successful for a long period, not just in terms of economic growth but also in terms of great dynamism in their exports, low rates of inflation, high rates of savings and rather equitable 
distribution. Even though several of these countries had high Balance of Payments current account deficits, this had been seen as acceptable for quite a long time both by analysts and markets alike, for two reasons; firstly, these deficits were financing very high investment rates; secondly, as mentioned above, the current account deficits did not originate in fiscal deficits - on the contrary, the Asian economies had fiscal surpluses - but were caused by private sector deficits.

So what went wrong? Clearly there were problems in the Asian economies, including serious weaknesses in their domestic financial systems and in their governance (see below). However, there is another causal factor, which relates more to the international dimension, and in particular to the behaviour of international capital flows. Though really important, this aspect has not received sufficient systematic attention in analyses of the Asian crisis.

This explanation is based on certain imperfections of international capital markets, that have always been there, but whose impact has increased due to technological developments, which allow the wheels of international finance to turn far faster than before. As pointed out above, this highly mobile capital plays positive roles. However, it can have very problematic aspects. Paradoxically, these negative effects can be strongest for economies that either are - or are perceived as about to become - highly successful. We could call it the curse of the successful economy; more technically, we could call it "financial Dutch disease".

A successful economy - like those of the previously so-called Asian Tigers - offers high yields and profits to international investors. If these investors can find ways to enter these economies, or if their entrance is facilitated by capital account liberalisation, they will rush in. This surge of capital inflows will affect key macro-economic variables. Exchange rates tend to become greatly over-valued; the prices of key assets - like shares and land - tend to rise significantly and quickly. As a result there is both an increase in real income (as imported goods become cheaper) and an 
increase in perceived wealth (as asset prices become at least temporarily higher), as well as a perceived increase in future income. Banks can increase lending, lifting liquidity constraints. As a result of these factors, individuals consume more; also private companies increase their investment.

The sum of these individual decisions has macro-economic implications. The current account of the Balance of Payments deteriorates, often quite rapidly, as both consumption and investment rise. Initially, this is not seen as a problem, as foreign lenders and investors are happy to continue lending/investing, given high profitability combined with the perception of low risk, as they are going into what is broadly seen as a successful economy.

Then, something changes. The change may be domestic or international. It may be economic or political. It may be an important change or a relatively small one. The key element is that this change triggers a sharp modification in perceptions, leading to a large fall in confidence in the economy among internationally mobile investors; these can be both foreign investors in the country or nationals able and willing to take their liquid assets out of the country.

The change of perceptions tends to be both large and quick. A country that was perceived as a successful economy or a successful reformer - for which no amount of praise was sufficient suddenly is seen as fragile, risky and crisis prone. The change of perception tends to be far larger than the magnitude of the underlying change warrants. The frightening aspect is that there is a very strong element of self-fulfilling prophecy in the change of perception. Currency crises happen to a significant extent because lenders and investors fear they can happen. The fact that they first stop lending and investing and then pull out contributes greatly to make their worst nightmares come true. As a result, there can be much overshooting. Exchange rates can collapse, as can stock-markets and property prices. Governments or central banks are forced to raise 
interest rates to defend the currency. As a result, banking systems become far more fragile than they were before, as previous weaknesses are magnified and new ones emerge.

An additional problem is contagion. Countries in the same region, or with weaknesses seen to be similar as the crisis country can also suffer from a parallel change of perception by investors. The crisis spreads to other countries, including to those with basically good economic fundamentals. The latter may suffer somewhat less, but may, if unlucky, be caught up in the whirlwind of deteriorating perceptions.

This pattern helps explain the currency and banking crises in the Southern Cone of Latin America in the early 1980s; it helps explain the Mexican peso crisis and the Tequila effect. It also provides important elements to understand the 1997 Asian crises. Of course there are significant differences between these crises, and the previous ones throughout the centuries (Kindleberger, 1984). But the boom-bust behaviour of short-term lenders and investors, driven not just by real trends (which they help shape), but by dramatic changes in perceptions is a common denominator to these different crises.

There is a relevant academic literature which explains why capital and financial markets are special, in that - though generally functioning well - they are prone to important imperfections. Factors like asymmetric information and adverse selection play an important role in explaining these imperfections, given that financial markets are particularly information intensive (Stiglitz, 1994). Furthermore, as Keynes (1936) showed with his well-known metaphor of the beautycontest, there are strong incentives to follow the herd in financial markets, as each individual short-term investor, lender or fund manager tries to choose the investment or loan that he/she thinks likeliest to be chosen by other investors or lenders, as his colleagues' assessment will be a crucial element in determining short-term prices. 
Also of relevance for understanding the Asian crisis is the concept self-fulfilling attacks, that is crises arising without obvious current policy inconsistencies, see Obstfeld (1996) and GriffithJones (1998). In this model, speculative attacks are basically caused not by bad fundamentals, but by future expected shifts of macro-economic policies, which will be caused by the attack itself. In these models, the attitude of speculators and investors is crucial to whether an attack occurs. This implies multiple equilibria for exchange rates. The existence of self-fulfilling attacks and multiple equilibria implies that good macro-economic fundamentals are a very important necessary but not a sufficient condition for avoiding currency crises. Stiglitz (1998) illustrates this clearly by comparing small open economies to rowing boats on an open sea. Bad steering or even more leaky boats significantly increases - or makes inevitable - a disaster. However, the chances of being overturned are significant no matter how well the boats are constructed and steered.

As Wyplocz (1998) rightly argues, there is at present limited understanding of what triggers selffulfilling attacks. As a consequence, self-fulfilling attacks are fundamentally unpredictable. It is interesting that the main explanations given by market actors for different recent crises (e.g. Mexican peso crisis, crises in different Asian countries) tend to be rather different ones. As a result, developing countries' policy-makers face the daunting task of "playing to moving goalposts," to avoid crises. Naturally there are conditions of vulnerability that can be identified (such as the ratio of short-term foreign exchange debts plus the stock of assets that can easily leave the country divided by the level of foreign exchange reserves, or high current account deficits). But such vulnerability indicators do not imply that crisis a will occur. Many countries have such high vulnerability indicators but do not have a crisis. On the other hand, some of these indicators may be relatively low and/or improving (e.g. the current account deficit was relatively low and improving in South Korea in 1997) and the country can still have a crisis. These patterns confirm the multiple-equilibrium character of currency and other crises, where a triggering event can cause a dramatic change of perception, make these vulnerability indicators become important, and precipitate a large change of investor and creditor flows 
Further research is required into conditions of vulnerability and nature of triggering events, to be able to predict risk of - and, above all, improve prevention of - currency crises. However, measures are also necessary to shelter developing countries from these volatile and unpredictable flows and their negative effects, whilst continuing to encourage more stable flows, especially if as in the case of foreign direct investment - they bring other valuable benefits.

Domestic policies - at the macro-economic level, to the domestic financial sector, and the possible regulation of short-term capital inflows - can of course play an important role. However, they are difficult to implement perfectly. As a consequence, an international effort is also required to make costly currency crises in developing and transition countries less likely and to manage them better if they do occur.

In the $19^{\text {th }}$ Century, the rapid development of private banking implied frequent national banking crises. The establishment and development of national regulatory bodies and of Central Banks with lender of last resort facilities made such crises less frequent (Griffith-Jones and Lipton, 1987). Similarly, the rapid development of global capital and banking flows in the latter part of the $20^{\text {th }}$ Century implies the need for new measures of global governance to regulate those flows. These will include better regulation of international credit and portfolio flows, as well as improvements of the lender of last resort facility and possible development of international debt workout procedures. We now turn to these options.

\section{Crisis Prevention}

\section{A The IMF Proposals}


The Asian crisis has provoked a vast amount of discussion and reflection in the international community. It is hoped that lessons can be drawn on what needs to be done to reduce the probability of future crises. A number of interesting proposals are currently being discussed, both by the IMF and others. This section will focus on the three main proposals for crisis prevention being put forward by the IMF: improvements to the quality of information supplied by countries to the IMF and the public, together with improved IMF surveillance; the strengthening of domestic financial systems by improving regulation and supervision and increasing financial sector transparency; and encouraging the 'prudent and properly sequenced' liberalisation of capital flows. These proposals will be examined below, and the analysis will show that while each of them has a role to play in strengthening the international financial system, it is unlikely that these measures alone could prevent future crises. 


\section{Improving the Quality of Information}

The Asian crisis has provoked calls for improvements to information disclosure, data dissemination and international surveillance. Similar demands were made in the wake of the Mexican peso crisis, when emphasis was placed on better information regarding national economic policy. The current emphasis is on improved data in other areas such as foreign exchange reserves, short-term foreign currency denominated debt, and the state of the financial system. The question of accurate information is made even more complex due to the increased use of off-balance sheet transactions such as forward contracts and other financial derivatives. The Asian crisis has highlighted this issue as the true foreign exchange positions of some countries were hidden by central bank derivative transactions and positions. Therefore, improved information on derivatives would be particularly useful, and the role of the IMF in improving this information is very valuable.

Firstly, the IMF has stated that countries must be encouraged to improve the quality of information that they make available to the fund and to the public (Camdessus, 1998a and Interim Committee, 1998). Transparency and the timely release of economic information provide the bare bones of crisis prevention. It is now clear that there were major deficiencies in the quality of information available to the markets on the countries most severely affected by the Asian crisis. Once the facts emerged, particularly data on foreign exchange reserves and short-term foreign denominated debt, the markets over-reacted and the crisis deepened.

In order to encourage transparency in, sometimes reluctant, emerging market economies it was proposed at the recent Spring meeting of the IMF and the World Bank that the Fund could delay the completion of its annual Article IV health check of a country's economy if it is not satisfied with the information being disclosed. The IMF also wants to encourage more emerging market economies to make public the results of these consultations with the Fund through the issuance of Press Information Notices (PINS) on the IMF website. 
Secondly, IMF surveillance needs to be tighter and more far-reaching. In particular, the financial sector needs to be examined in more detail. The IMF and the World Bank have recently been building up their financial sector surveillance capacity. At a recent G7 meeting in Washington, proposals to create new surveillance structures were made (discussed further below) .

Thirdly, efforts need to be made to improve transparency on the part of the IMF itself. The establishment of the Special Data Dissemination Standard (SDDS) in 1996 and the Dissemination Standard Bulletin Board (DSBB) on the IMF website, are testament to the Fund's commitment to improve data dissemination in the aftermath of the Mexican peso crisis. The IMF is currently looking at ways in which the SDDS could be broadened and strengthened, to include data on reserve related liabilities, central bank derivative transactions and positions, debt, particularly short-term debt, and the health of the financial sector (Interim Committee, 1998). However, some of these areas will involve problems concerning the international compatibility of reporting standards.

The Asian crisis has led to requests that the IMF be obliged to inform the markets when it thinks a country is heading for a crisis. The dangers of "whistle blowing" are clear: it could compromise the Fund's position as confidential advisor to member countries, and a public warning may provoke the very crisis that it is trying to prevent. However, the recent meeting of the IMF's Interim Committee proposed developing a 'tiered response' whereby the Fund would give increasingly strong, and ultimately public, warnings to countries which it believed were heading for trouble (Interim Committee, 1998).

While all commentators on the Asian crisis are agreed that improved information disclosure and tighter surveillance would be helpful, these changes are not sufficient to prevent future crises. In the first place, the attempts to implement greater transparency in the aftermath of the Mexican 
crisis have revealed the difficulties involved. Yet getting data on public finances is much easier than obtaining information on private capital flows. As Stiglitz states:

In a world where private-to-private capital flows are increasingly important, we will need to recognize that monitoring and surveillance are going to be especially challenging. The growing use of derivatives is increasingly making the full disclosure of relevant information, or at least the full interpretation of the disclosed information, even more difficult. (Stiglitz, 1998, p8)

In addition to the problems of obtaining and interpreting information on private capital flows, there are the difficulties involved in obtaining and interpreting information on the financial sector. Firstly, criteria for assessing the strength of bank and non-bank financial sector institutions are far from standard across countries, making any interpretation very difficult. Secondly, information on the state of the financial sector can be misleading as the health of financial institutions will deteriorate in a crisis.

Moreover, even if information and transparency were to be greatly improved, it is doubtful that this will necessarily lead to better investment decisions and the removal of the threat of market over-reactions. It has been shown that in the lead up to the Asian crisis, investors and lenders were well aware of some of the problems the worst hit countries were experiencing (see for example Wade and Veneroso, 1998 and Stiglitz, 1998b). Yet they did not adjust their lending and investment until the crisis hit. A recent World Bank report points out that while most of the lending was done by seemingly well-regulated institutions in the advanced countries:

foreign lenders and investors were not restrained by inadequate financial statements, high short-term debt, or the unhedged foreign exchange exposure present in the financing structure of east Asian banks and firms. (World Bank, Global Development Finance 1998 report cited in the Financial Times, March 25 1998, p18) 
As discussed above, this apparent anomaly can be put down to the herd behaviour of market participants. An analysis of the Mexican peso crisis showed that the problems associated with market over-optimism (or 'irrational exuberance' as Greenspan calls it) followed by market overpessimism, were more to do with the behaviour of fund managers than with the lack of information available (Griffith-Jones, 1996). Keynes' analogy of the beauty contest shows how success for international investors, often operating in unfamiliar markets, depends on accurately judging what average opinion will be (Griffith-Jones, 1998). Their incentive structure leads to herd behaviour, as their reputation will be damaged if they loose money while others make profits, but they will not suffer if they incur losses together with other market participants. Therefore, investors invariably base their decisions on the general perception of the market, rather than on a systematic analysis of economic fundamentals.

It is often argued that markets judge countries according to their fundamentals, and crises usually occur because of some change in fundamentals caused by external shocks or policy mistakes. Both the peso crisis and the Asian crisis have led to warnings on the importance of sound economic fundamentals in emerging market economies. However, in the case of both Mexico and the Asian countries, there were no changes to fundamentals significant enough to account for the severity of crises (see Stiglitz, 1998; p2, Rodrik, 1998, p5; Fischer, 1998, p9; Wolf, 1998; and Wyplosz, 1998).

\section{Strengthening Domestic Financial Systems}

Problems in the domestic financial systems of the worse affected countries are central to the IMF analysis of the Asian crisis (IMF, 1997 and Fischer, 1998). The main problems are believed to be: weak financial institutions; inadequate bank regulation and supervision; and the relations between government, banks and corporations (referred to as 'crony capitalism'). Financial sector weakness has often been a contributing factor for countries experiencing macro-economic difficulties. Therefore, strengthening domestic financial systems is a core element of the IMF strategy for 
crisis prevention. The updated IMF 'World Economic Outlook' published in December 1997 states:

recent events clearly demonstrate the crucial importance of strong financial institutions operated in accordance with established principles of sound banking and of rigorous transparency in the provision of economic and financial information. In this context, the emerging market countries need to move as quickly as possible to adopt the core principles on banking supervision. (IMF, 1997, p45)

A number of recent publications have examined how domestic financial systems could be strengthened. In 1997, the Basle Committee on Banking Supervision published its 'Core Principles for Effective Banking Supervision', developed by a working group consisting of representatives of the Basle Committee and emerging market countries. ${ }^{1}$ In 1998, the IMF published Towards a Framework for Financial Stability which was designed as a first step in building a framework that could be used in the Fund's surveillance of its members' financial sectors. The IMF's work on financial systems has focused on the banking system, due to its primary role as financial intermediary in many member countries and the limits of staff expertise. However other institutions, such as the International Organisation of Securities Commissions (IOSCO), have been compiling 'best practices' for their sectors of the financial system. ${ }^{2}$

The key aspects of a sound financial system outlined in Towards a Framework for Financial Stability include: transparency of the financial system; competent management; effective risk control systems; adequate capital requirements; lender-of-last-resort facilities; prudential regulation; a supervisory authority with sufficient autonomy, authority, and capacity; and supervision of cross-border banking (IMF, 1998).

1 'Core Principles for Effective Banking Supervision' is annexed to the main text in IMF (1998)

2 IOSCO's 'Principles and Recommendations for the Regulation and Supervision of Securities Markets' is annexed to the main text in IMF (1998). 
The role of the IMF in the surveillance of domestic financial systems has also come under scrutiny recently. Limitations of staff resources and expertise mean that IMF surveillance in this area would normally focus on identifying weaknesses in the financial systems of member countries which could have a significant impact on the macro-economic situation. The Fund, as it stands, cannot oversee the regulatory and supervisory authorities in each country, or address problems in other areas of the financial system (IMF, 1998, p1).

As we saw above, the Fund and the World Bank have been increasing their financial sector surveillance capacity. At the G7 meeting in April 1998, Canada and Britain proposed establishing a joint surveillance unit from the IMF and the World Bank. The proposed unit would be responsible for designing financial sector reform strategies in crisis situations and for carrying out surveillance of national financial regimes in non-crisis countries.

However, establishing effective risk management and sound regulatory and supervisory systems in all IMF member countries would be a huge task. As Rodrik notes:

Putting in place an adequate set of prudential and regulatory controls to prevent moral hazard and excessive risk-taking in the domestic banking system is a lot easier said than done. Even the most advanced countries fall considerably short of the ideal, as their bank regulators will readily tell you. (Rodrik, 1998, p7)

Stiglitz echoes these concerns when he writes:

Building robust financial systems is a long and difficult process. In the meantime, we need to be realistic and recognize that developing countries have less capacity for financial regulation and greater vulnerability to shocks. (Stiglitz, 1998b, p8)

The reform of the domestic financial sector in the Asian countries and elsewhere will, therefore, be lengthy and complex. Additionally, as noted above, the state of the financial sector is likely to deteriorate in a crisis. Therefore, in countries which exhibit signs of weakness, it might be prudent for the regulating authorities to consider the likely effects of major economic changes 
such as would occur in a currency crisis, on the quality of bank assets. This could be done by running simulations which predict the impact of changes to the exchange rate, interest rates, and value of property and shares given as guarantees to loans. Furthermore, the current emphasis of the IMF, for reasons cited above, is on improvements to the banking sector, particularly to regulation and supervision. Yet analyses of the Asian Crisis have shown that much of the foreign borrowing was by the non-bank private sector: one third in South Korea, about 60 per cent in Malaysia and Thailand, and around two thirds in Indonesia (Akyuz, 1998, p3). However, it would be extremely difficult to regulate the foreign borrowing of private companies, as Stiglitz notes:

No country can, does, or probably should regulate individual corporations at the level of detail that would be required to prevent the foreign exchange and maturity mismatches that arose. (Stiglitz, 1998b, p3)

\section{Prudent capital account liberalisation}

The third strand in the IMF crisis prevention strategy concerns encouraging countries to liberalise capital flows in 'a prudent and properly sequenced way' (IMF, 1998, p4). Capital account liberalisation involves both costs and benefits. The main benefits include: the increased availability of finance for trade and investment in recipient countries; the international diversification of risky assets; and increased efficiency in domestic financial systems. However, the costs can also be substantial and include: macro-economic instability due to the speculative inflow of foreign capital, and the loss of policy autonomy for liberalising countries.

In the IMF analysis, capital account liberalisation is problematic when macro-economic conditions are not adequate, or when it is not accompanied by reforms to the domestic financial system. Camdessus states that capital account liberalisation should be 'bold in its vision, cautious in its implementation' (Camdessus, 1998, p4). He outlines the basic necessary conditions for success as follows: a sound macro-economic policy framework; reforms to the financial system; that the 
opening of the capital account should be phased to take account of the country's macro-economic situation and the state of domestic reforms; and timely and accurate information disclosure.

The Asian crisis has highlighted the problems that can result when fragile emerging market economies open their capital accounts. The sometimes irrational behaviour of market participants can have deeply damaging effects on countries which have seen little change in their economic fundamentals. The IMF position, that capital account liberalisation should be prudent, and phased to take account of prevailing economic conditions, appears to be sensible. McKinnon and others have stated that full capital account liberalisation should be the last step, after the consolidation of other liberalising measures and the strengthening of the domestic financial system (McKinnon, 1991). Countries should also be able to reverse liberalisation measures if a change in the macroeconomic situation calls for it. In particular, countries should be able to use market-based measures to discourage excessive surges of short-term flows as has been the case in Chile (see below).

The three main proposals examined here, improvements to the quality of information and surveillance, strengthening domestic financial systems, and the prudent liberalisation of capital flows, would all contribute to strengthening the international financial system. Shaping an effective crisis prevention strategy, however, will require sharper tools.

\section{B Regulating and/or taxing capital inflows}

\section{National Measures}

This section will focus more on suggestions for international measures to discourage excessive surges of short-term and easily reversible capital and debt flows. However, we will start by examining measures that recipient countries can take to discourage such surges. Indeed, some countries (e.g. Chile and Colombia) have implemented measures (such as taxes and non- 
remunerated reserve requirements on flows during a fixed period) to discourage excessive surges of short-term capital flows. Their aim has been threefold:

(1) To change the structure of capital inflows in order to increase the share within total capital flows of foreign direct investment and long-term loans, and above all to decrease the share of short-term and potentially reversible flows, by discouraging the latter. The lower level of shortterm flows makes the country less vulnerable to currency crises.

(2) To increase the autonomy of domestic monetary policy, as measures such as non-remunerated reserve requirements allow the recipient country to maintain higher national interest rates than the international ones; this is useful for controlling inflation and curbing excessive growth of aggregate demand - without attracting excessive capital inflows; and

(3) To curb large over-valuation of the exchange rate, caused by a surge, which discourages growth of exports and poses the risk of growing and unsustainable current account deficits.

Several studies in the mid-1990s (Ffrench-Davis and Griffith-Jones, 1995 and Khan and Rheinhart, 1995) showed how measures to discourage inflows - in countries like Chile and Colombia - have been a contributory factor to a relatively more successful management of capital inflows. Furthermore, these measures to discourage short-term inflows are widely seen as one of several reasons (with prudent macro-economic management being perhaps the main one) why Chile and Colombia were amongst the few countries in Latin America to be relatively unaffected by the tequila crisis in 1994-1995 and by the 1997-1998 Asian crisis. In the case of Chile, there is econometric and other evidence that the disincentives to short-term inflows have contributed fairly significantly to reduce the inflow of short-term, interest arbitraging funds, and their proportion of total capital inflows (Agosin, 1996; Budnevich and Le Fort, 1997). Also, Chilean policy-makers saw as important that - at a time of declining U.S. interest rates in the early 1990s and a booming economy in Chile - the Central Bank was able to increase rather than lower interest rates in order to maintain macro-economic equilibrium (personal communication with 
Ricardo Ffrench-Davis, then Chief Economist at the Central Bank). There is also evidence that total capital flows to Chile were lower than they would have otherwise been (though a clear counterfactual is always difficult) and that as a consequence the resulting strengthening of the currency has been less than it would have otherwise been.

Two of the attractive features of the Chilean measures are: that they are market-based, rather than quantitative (Fischer, 1997), and that they apply to practically all short-term flows, thus simplifying administrative procedures and reducing possibilities of evasion, even though some evasion is naturally inevitable. Colombia has a similar, though more complex, approach to Chile's. Its measures are also broadly seen as successful, particularly in discouraging short-term flows and improving the term structure of total capital flows. It is interesting that the IMF (1995), the World Bank (1997) and the BIS (1995) (that is, all the major international financial institutions) now explicitly recognised that - though having some limitations and minor microeconomic disadvantages - market measures taken by recipient governments to discourage shortterm capital flows do play a positive role, if they are part of a package of policy measures that include sound macro-economic fundamentals as well as a strong and well regulated domestic financial system. This support for recipient countries discouraging short-term flows during surges as a useful measure has grown since the Asian crisis (Stiglitz, 1998, Wolf, 1998, Rodrik, 1998, Radelet and Sachs, 1998). 
There is therefore a growing consensus - further strengthened after the Asian crisis - that, though no panacea, discouraging short-term flows by recipient countries is one of several useful policy instruments for better management of capital flows and for reducing the risk of currency crises. It would therefore seem advisable for recipient countries to implement such a policy during periods of surges, and for international institutions like the IMF to encourage countries adopting such measures, in a temporary way, at times when countries receive excessive inflows of short-term capital and when other key conditions, e.g. good macro-economic fundamentals, are in place.

\section{International Measures}

The question, however, needs to be asked whether measures to discourage excessive short-term capital inflows by recipient countries are enough to deal with the problem of capital surges and the risk of their reversal. There seem to be at least three strong reasons making complementary action by source countries necessary. Firstly, not all major recipient countries will be willing to discourage short-term capital inflows, and some may even encourage them. A recent example of the latter are the tax and regulatory measures taken in Thailand to encourage the Bangkok International Banking Facility, which de facto encouraged short-term borrowing (Boorman, 1998). Secondly, even those recipient countries - like Chile, Colombia and Malaysia - which have deployed a battery of measures to discourage short-term capital inflows have on occasions found these measures insufficient to stem very massive inflows. Thirdly, if one or several major emerging countries experience attacks on their currencies, which also result in difficulties to service their debt in full, it is far more probable than in the past that those countries will be forced to seek official funding to allow them to continue servicing their foreign exchange obligations in full, rather than being able - as in the past - to restructure such obligations. As the IMF (1995) pointed out, one important reason for the latter is the difficulty of restructuring securitised exposures owned by a diversity of investors. Because international official funding plays such a large role in providing finance during such crises, to avoid moral hazard, there is a clear need for international and/or source country regulation that will discourage excessive short-term capital 
inflows that may be reversed, contributing to a costly currency crisis. If such international and/or source country regulation is not developed, international private investors and creditors will continue to assume excessive risks, in the knowledge that they will be bailed out if the situation becomes critical. This is the classical moral hazard problem.

As a consequence, it is important to complete and improve international prudential supervision and regulation, to adapt it to the new scale and nature of private flows. Indeed, it is essential to fill existing regulatory gaps. Calls for improved supervision and regulation of capital flows to emerging markets internationally and/or by source countries began to be heard after the Asian crisis. For example Martin Wolf (1998) wrote in the Financial Times "After the crisis, the question can no longer be whether these flows should be regulated in some way. It can only be how." In the same spirit, the G-24 in their April 1998 statement called for the creation of a Task Force that, amongst other aspects, would examine: "more effective surveillance of the policies of major industrialised countries affecting key international monetary and financial variables, including capital flows." Soros (1998) has argued forcefully that international capital and credit flows need to be regulated.

There are two types of flows to emerging markets where additional regulation and supervision seems particularly necessary, as they seem insufficiently regulated and their surges, as well as outflows, have played a particularly prominent role in sparking off recent currency crises. One of these are short-term bank loans; the other are easily reversible portfolio flows.

As regards short-term bank loans, they played a particularly important role before and during the Asian currency crises, especially in some countries, such as South Korea. In principle, bank loans (including short-term ones) are already regulated by industrial countries' Central Banks or their other regulators; these national regulations are co-ordinated by the Basle Committee. Such regulations include requirements for provisioning against potential future losses on lending to 
emerging countries (with a particularly detailed methodology developed in the Bank of England with its provisioning matrix) and capital adequacy requirements. However, existing regulations were not enough to discourage excessive short-term bank lending to several of the Asian countries. A key reason was that until just before the crisis most of these Asian countries (and particularly countries like South Korea) were seen by everybody including regulators as creditworthy (for evidence see again Radelet and Sachs, 1998). This was caused not just by asymmetries of information and disaster myopia (Griffith-Jones, 1998) but also by the excellent record of the East Asian countries described above. Another, perhaps somewhat secondary but also important reason, seems to have been current regulatory practice. ${ }^{3}$ This implies that for nonOECD countries (which included South Korea until recently) loans of residual maturity of up to one year have a weighting of only 20 per cent for capital adequacy purposes, whilst loans over one year have a weighting of 100 per cent for capital adequacy purposes. As a result of this rule, short-term lending is more profitable for international banks. Therefore, to banks' economic preference for lending short-term, especially in situations of perceived increased risk, as this allows them to have more liquid assets that can be more easily not renewed if the situation deteriorates, is added a regulatory bias that also encourages short-term lending. The capital adequacy weighting differential appears too large in favour of short-term loans for non-OECD countries, resulting in excessive incentives for short-term lending. A narrowing of this differential may therefore be desirable.

Further measures to discourage excessive surges of short-term bank loans to emerging markets as suggested by Witteveen (1998) also requires further study. However, care must be taken that any measures adopted to discourage excessive short-term loans do not affect directly or indirectly, trade credit, as this is essential.

\footnotetext{
${ }^{3}$ Communication with Coling Miles, Bank of England.
} 
As regards portfolio flows to emerging markets, there is at present no regulatory framework in source countries or internationally, for taking account of market or credit risks on flows originating in institutional investors, such as mutual funds (and indeed more broadly for flows originating in non-bank institutions). This is an important regulatory gap that needs to be urgently filled, both to protect retail investors in developed countries and to protect developing countries from the negative effects of excessively large and potentially volatile portfolio flows.

As regards retail investors from developed countries, the need to protect them by regulation remains, in spite of important efforts being made to improve information by the regulatory authorities, especially in the US (see d'Arista and Griffith-Jones, 1998). The key reason is that it is practically impossible to improve sufficiently information and disclosure for retail investors on risk/return for their investments in emerging markets, because of the conceptual complexities involved, and especially given that the problems of asymmetric information and principal agency are particularly large for this category of investments (Mishkin, 1996).

As regards emerging market countries, the Asian crisis confirms what was already clearly visible in the Mexican peso crisis. Institutional investors, like mutual funds, given the very liquid nature of their investments can play an important role in contributing to currency crises. It seems important to fill this regulatory gap and introduce source country regulation to protect their domestic investors (especially the less informed retail investors), and discourage excessive surges of portfolio flows to emerging markets. This could perhaps best be achieved by a risk-weighted cash requirements for institutional investors, such as mutual funds. These cash requirements would be placed as interest-bearing deposits in commercial banks. It should be stressed that this proposal is in the mainstream of current regulatory thinking, which sees risk-weighting as the key element in regulation (for an authoritative statement from the US Federal Reserve Board, see Phillips, 1998). 
Introducing a risk-weighted cash requirement for mutual funds (and perhaps other institutional investors) would require that standards be provided by regulatory authorities. In the United States, these standards would result from consultations among the Securities and Exchange Commission with the Federal Reserve Board and the Treasury. In the UK, the standards would result from consultations between the Securities Investment Board, with the Bank of England and the Treasury. Weight should be given to the views of market analysts such as credit rating agencies, as well as particularly to the views of international agencies such as the IMF and BIS, with a long expertise in assessing countries' macro-economic performance. This would provide guidelines for defining macro-economic risk and for its measurement in determining the appropriate level of cash reserves. Thus, cash reserves would vary according to the macroeconomic risks of different countries.

The guidelines for macro-economic risk (which would determine the cash requirements) would take into account such variables as the ratio of a country's current account deficit (or surplus) to GDP, the level of its external debt to GDP, the maturity structure of that debt, the fragility of the banking system, and other country risk factors. Factors such as custody-related risks (which already greatly concern securities regulators) could be included where relevant. It is important that quite sophisticated analysis is used, to avoid simplistic criteria stigmatising countries unnecessarily and arbitrarily. The views of the Central Bank, the Treasury, the IMF and the BIS should be helpful in this respect, especially given the long experience of foreign exchange crises and their causes that the international community has acquired.

The fact that the level of required cash reserves capital charge would vary with the level of perceived "macro-economic risk" would make it relatively more profitable to invest more in countries with good fundamentals and relatively less profitable to invest in countries with more problematic macro or financial sector fundamentals. If macro-economic or financial sector fundamentals in a particular country deteriorate, investment in them would decline gradually, 
which hopefully would force an early correction of macro-economic policy, and, once this happened, a resumption of flows would take place; this smoothing of flows would hopefully discourage the massive and sudden reversals of flows that sparked off the Mexican peso and Asian currency crises, making such costly crises less likely. Though the requirement for cash reserves on mutual funds' assets invested in emerging markets could increase somewhat the cost of raising foreign capital for them, this would be compensated by the benefit of a more stable supply of funds, at a more stable cost. Similarly, retail investors in developed countries could get slightly lower yields, but be assured of far lower risks and lower volatility. Given the dominant role and rapid growth of institutional investors in the US and UK, this proposal - a risk-weighted cash requirement capital charge on mutual funds - could be adopted first in these two countries without creating significant competitive disadvantages. However, once implemented in the major countries - like the US and the UK - efforts to harmonise such measures internationally would need to be given urgent priority for discussion at the global level by the International Organisation of Securities' Regulators (IOSCO), so as to prevent investments by mutual funds being channelled through off-shore intermediaries that did not impose these cash requirements.

The suggested measures would follow a similar process as adopted first by G-10 Central Banks individually, on provisioning and capital adequacy on bank loans, which were then co-ordinated for all G-10 countries in the Basle Committee; the procedure would be similar, and the mechanism would be based on the same principle as capital adequacy, but would be clearly adapted to suit the institutional features of mutual funds, where shareholder capital backs 100 per cent of invested assets.

Finally, it is important to stress that additional regulation of mutual funds should be symmetrical with regulation of other institutions (e.g. banks) and other potentially volatile flows, e.g. excessive short-term bank credit, discussed above. Emphasis on regulation of institutional investors like mutual funds is necessary because they are clearly under-regulated, in comparison with other 
financial institutions, principally because their growth is so recent, particularly in relation to their increased investment in emerging market.

It can be concluded that though better disclosure of risk is both difficult and very valuable, practical difficulties which have been analytically illuminated by the theory of asymmetrics imply that better information and disclosure needs to be complemented by other measures to both achieve better investor protection and diminish potential volatility of flows, which is particularly damaging for developing countries. A complementary measure to improve disclosure - riskweighted cash requirements - have been discussed. Naturally other proposals - or variations of the present proposal - could be considered. What is clearly important is that meaningful measures should be taken to help stabilise capital flows to emerging markets. It is also important to stress that, given the evolution of the markets, past strategies, such as prohibiting investment in certain markets, are clearly no longer appropriate. Such prescriptive rules could have potentially negative effects on investors (who could lose profitable opportunities) and some emerging market economies, as their access to portfolio flows could be curtailed either in general, or - even worse - abruptly in times of macro-economic difficulties. The central proposals made here, of a riskweighted approach - via capital charge cash requirements - would seem better as changes in cash requirements would be more gradual, thus contributing to smooth flows, which is the desired objective for the developing economy, and which would also give greater protection to developed country investors. Furthermore, risk-weighted cash requirements for institutional investors are consistent with modern mainstream regulatory thinking which sees risk weighting as the key element in regulation.

The above proposals have certain important similarities (especially in their objectives) with Soros' 1998 interesting proposal. The latter may be considered more radical because it implies setting up and funding a new institution, the International Credit Insurance Corporation (ICIC) which may provoke resistance. According to Soros' proposal, this new authority would guarantee 
international loans for a modest fee. On the basis of detailed data on countries' total borrowing, and an analysis of the macro-economic conditions in the countries concerned, this authority would set a ceiling on the amounts it is willing to insure. Up to those amounts the countries concerned would be able to access international capital markets at prime rates. Beyond these, "the creditors would have to beware" (Soros, 1998) as there would be no cover. Like the other above proposal, Soros' idea has the important virtue that it would tend to cap excessive surges of capital flows while encouraging moderate flows, as the ICIC would not just perform an insurance, but also a signalling role. The proposal as made seems to refer more to international loans, but it could also possibly be extended to other flows, like portfolio ones. The key problem of Soros' proposal may be a serious moral hazard, unless the fee charged is high enough to appropriately cover risks of non-payment; the latter risk is of course hard to estimate ex-ante. However, the Soros proposal is interesting because if implemented it would smooth flows, encouraging them up to a "reasonable" level, and discouraging them beyond that. It is also of interest because it explicitly tries to tackle imperfections in international credit markets, and in particular herd behaviour.

It would seem desirable to complement measures for improving and completing international prudential supervision for credit and capital markets as described above with a measure of international taxation. A measure that deserves attention is Tobin's proposal to levy an international uniform tax on spot transactions in foreign exchange. This proposal, initially made by James Tobin in 1972, has received much attention recently, particularly given turbulence on foreign exchange markets, both in Europe (1992) and in the emerging markets. Ul Haq, Kaul and Grumberg (1996) explore the issues in depth; Kenen (1996) in that volume in particular shows the practical feasibility of such a tax. Tobin's proposal is for a very low tax on all currency transactions. The aim would be to slow down speculative, short-term capital flows movements (which would be more affected as by definition they cross borders often, and would be taxed every time), while having only a marginal effect on long-term flows. This would achieve two objectives; it would increase the autonomy of national authorities for monetary and macro- 
economic policy, with a bit more independence from the effects of international money markets. Such an autonomy would be particularly valuable for LDCs, to the extent that their economies adapt less easily to external shocks and because their thinner financial markets are more vulnerable to the impact of external capital inflows and outflows. The second objective of the tax (Tobin, 1996) is to make exchange rates reflect to a larger degree long-run fundamentals relative to short-range expectations and risk. Volatility - in particular departures from fundamentals would be diminished. So would the likelihood of currency crises.

This proposal is different from the others listed above, in that it may seem more radical. However, there is a widespread feeling, even in private circles, that financial liberalisation may have proceeded too far or at least too fast, and that financial liberalisation carried to the extreme may even risk damaging the far more important trade liberalisation whose benefits are far more universally recognised. Furthermore, a new tax with potentially high yields would be attractive to fiscally constrained governments. Part of the proceeds could also fund public goods like poverty alleviation and environment spending, especially in poorer countries. Therefore, a small tax on financial flows - which particularly discourages short-term flows - could be a welcome development. It could be introduced on a temporary basis for a fixed period, for example five years. This would be consistent with the fairly widespread perception that financial fragility and systematic risk are particularly high in the current stage of "transition" from regulated freer financial markets.

It can be concluded that one or several measures need to be taken internationally to make currency crises in emerging markets far less likely, and therefore ensure the efficient operation of the market economy in emerging markets, which should be a basis for sustained development. The objective of crises avoidance seems to require some discouragement and/or regulation of excessive and potentially unsustainable short-term inflows. Such measures would be most effective if they are applied both by source and recipient countries, if they avoid discouraging 
more long-term flows, if the rules designed are simple and clearly targeted at unsustainable flows and if they are complemented by good policies in the emerging economies.

As in medicine, so with currency crises; prevention is far better than cure. Therefore, it seems desirable to particularly emphasise crisis prevention measures. However, if prevention fails and major currency crises do unfortunately occur, measures need to be in place to manage them as well as possible. It is to this that we turn in the next section.

\section{Crisis Management}

\section{A The lender of last resort}

The first response when a large currency crisis starts unfolding in one or more countries is to activate quickly a sufficiently large "international lender of last resort" to provide the important public good of stability. The key institution in this has been the International Monetary Fund, both through its own resources and its catalytic role in attracting other resources.

A number of issues arise relating to the IMF's role as lender of last resort. The main ones seem to be: timing, scale, conditionality and ways to avoid moral hazard. We will discuss these briefly.

The issue of timing is crucial, as currency crises happen so quickly. Though the IMF and the international financial community have made important efforts to develop emergency procedures to speed up significantly the Fund's response in moments of currency crises, the response is still not fast enough. This implies that a currency crisis is able to unfold for a couple of weeks, before a financing package can be put in place. As markets move so fast and overact so much, a great 
deal of damage can occur in that period (e.g. there can be much overshooting of the exchange rate). Also, due to contagion the crisis can spread to other countries, adding to costs and problems.

The best solution seems to be to build on a suggestion made in a 1994 IMF paper ("Short-term Financing Facility"), and have preventive programmes; indeed, such a facility seems to have been established for the Philippines in early 1998. What this implies is that a request for a country's right to borrow from the IMF could be made before a crisis happens, for example during the time of an Article IV consultation. The country would only draw on this facility if a crisis occurred, but could do so immediately when it starts. This would, however, imply that the Fund would have a "Shadow programme" with the country, and therefore impose some policy conditionality, focusing on conditions that would make a currency crisis less likely. The Fund's conditionality would naturally be less tough than in the middle of a crisis, as far less draconian measures would be required.

The country would have to accept conditionality even while it was not receiving disbursements; however, the country would have the very important advantage of an automatic right to draw off a large credit (or at least a first tranche) immediately when a crisis started; naturally, the drawing of the credit would be accompanied by an immediate report to the Fund's Board, but no need for Board approval. This procedure would have the great advantage for the country (and the international community) that the immediate activation of the facility would reassure the markets more quickly, thus hopefully reducing the scale of the crisis and its cost.

A second crucial issue is the scale of the lending, by the IMF and others. Bagehot's (1873) classic advice on national lenders of last resort was that - to be effective in convincing markets such a facility must be able to "lend freely", that is virtually open-ended, or at least extremely large. The massive scale for an international lender of last resort, given the scale of assets in the 
private markets, poses a serious challenge for governments and central banks of the major countries. This challenge is made more difficult by the resistance of the US Congress to provide additional resources to the IMF, which are clearly necessary.

An additional serious problem, that has been insufficiently discussed, is that when such large volumes of IMF - as well as World Bank and Regional Development Bank - funding is channelled towards middle-income countries in crisis, funding available from those institutions for lowincome countries can fall drastically. This is a very negative indirect effect of currency crises.

Two types of measures can help alleviate the pressure on the IMF and governments as international lender of last resort. The first one is to reduce the likelihood of currency crises, by giving high priority to adopting measures along the lines discussed in Section III above. In particular it is necessary to limit moral hazard. Countries are not really subject to so much moral hazard, due to the dramatic economic, social and political costs of a currency crisis. Moral hazard, however, affects lenders, investors and fund managers; for this reason, it is essential that this moral hazard is curbed by appropriate preventive measures by source countries as well as internationally to regulate and/or discourage excessive easily reversible flows to emerging markets which could later precipitate a crisis, that would require an international lender of last resort.

The second measure to reduce the need for international public funding, is to attempt to involve the private sector in providing some of the liquidity required for the lender of last resort facility. Reportedly, this has already been suggested in an IMF confidential report. This would imply adopting the experience of the 1980s debt crisis, when the IMF assembled financing packages that included concerted or "involuntary" lending from creditor banks. However, as mentioned above, this may be somewhat more difficult, given the diversity of actors and the greater securitisation of instruments. This also makes it more important to develop orderly work-out procedures, as this will reduce the required scale for international lending of lender of last resort. 
It is interesting that some countries (e.g. Argentina) have recently already themselves arranged stand-by facilities with international banks, only to be used in case of a currency crisis. This facility, however, has not yet been tested.

A final issue is the nature of IMF conditionality that should accompany the large financial packages, linked to currency crises. A number of criticisms have arisen of IMF conditionality. For example, Feldstein (1998) has argued that IMF conditionality has been too intrusive and too comprehensive, trying to make dramatic changes in very short periods. Radelet and Sachs (1998) have further argued that the conditionality has not been appropriate in several important aspects, (e.g. bank closures, tightening of fiscal policy, excessive emphasis on full debt repayment) and that even some of these measures and their pace have "added to, rather than ameliorated, the panic". Their critique seems particularly strong on the abrupt shutting down of financial institutions without a more comprehensive programme for financial sector reform and no deposit insurance in place, which in Thailand and Indonesia only deepened the panic.

On macro-economic policy, the key new challenge for IMF (and country) programmes is to design appropriate macro-economic responses for currency crises that mainly originate in private sector imbalances, (higher private investment than private savings) and not, as traditionally IMF packages were accustomed to dealing with, public sector imbalances, reflected in fiscal deficits. Therefore the traditional IMF response - tightening fiscal policy - may either be totally inappropriate or insufficient. New elements need to be introduced, in the new context of private sector led deficits, like counter-cyclic macro-economic policy; greater focus has to be placed not just in post crisis macro-management, but in prudent fiscal and monetary management during periods of abundant capital inflows; this could for example even include cyclically adjusted taxation to curb excessive growth of private spending. Domestic prudential regulation of the financial sector could also include anti-cyclical elements; this could include stricter prudential regulation of short-term foreign exposure by banks. It could also imply limiting the value of 
assets (e.g. real estate) allowed to be used as guarantees for loans, when the value of such assets can fall significantly if a currency and financial crisis occurs.

\section{B Orderly workouts}

Official lending during crises in heavily indebted countries can lead to moral hazard problems. In terms of borrowers, this could lead to excessive risk-taking or the danger that countries might pursue imprudent economic policies, believing that they would be bailed out in the event of a crisis. However, this is extremely unlikely given the huge cost to a country of a currency crisis (Strauss-Kahn:1998). The risk of moral hazard is more on the lenders' side, as bail-outs mean that they do not have to bear the full risks of their investment decisions. Equally, a belief that a bail out is likely in the future could discourage lenders from carrying out adequate risk appraisals.

In the absence of orderly debt workout procedures, the alternative to official financial intervention would be to continue with the drawn-out negotiations of the type seen in the 1980s. In the aftermath of the 1980s debt crisis countries were denied access to international capital markets for a number of years, which had serious consequences for economic growth. Therefore a system is required which can bring about the rapid resolution of crises, while limiting the problems of moral hazard. There is now a general consensus among the international community that ways need to be found to involve private sector creditors at an early stage in crisis resolution in order to achieve equitable burden sharing vis-à-vis the official sector - in what Fischer has termed 'the bail-in question' (Fischer, 1998, p16, see also Interim Committee, 1998, p3).

This issue was also intensely debated after the Mexican peso crisis. ${ }^{4}$ At that time, it was recognised that recent changes to the international financial system would affect the nature of future sovereign liquidity crises. The key changes were the increased globalisation of financial

\footnotetext{
4 See for example, the Group of Ten (1996) and Eichengreen and Portes (1995).
} 
markets, changes in the composition of capital flows to emerging market countries, with an increase in debt in the form of securities, and a decrease in the likelihood that existing creditors would be prepared to offer new financing to a country experiencing a sovereign debt crisis (Group of Ten, 1996, p3).

Discussions at the time focused on ways to improve the existing mechanisms for dealing with such crises while minimising moral hazard for both creditors and debtors. Yet despite a great deal of support for some of the proposals put forward, the discussions did not result in any significant changes. The level of official financing used in the Asian crisis far exceeded that needed in Mexico, and in spite of official intervention the crisis has been more severe. Stiglitz has noted:

In spite of repeated resolutions that lenders should bear more of the cost of their risky decisions, the moral hazard problem in the 1990s is, if anything, larger, not smaller than it was in the 1980s. (Stiglitz, 1998b)

Therefore in the wake of the Asian crisis, this issue has emerged again and the IMF, among others, are reviewing the proposals discussed in the aftermath of the peso crisis which included: the establishment of international bankruptcy procedures; changes in the provisions of loan contracts and bond covenants; and IMF-supported debt moratoria (see Group of Ten, 1996, and Eichengreen and Portes, 1995). Each of these proposals has advantages and disadvantages.

Firstly, it has been suggested that the features of bankruptcy procedures within countries could be applied to sovereign debt. International bankruptcy procedures, it is argued, could prevent the problems which arise when individual creditors race to press their claims, giving countries the chance to restructure existing debts and secure new financing. However, this idea is unlikely to be put into practice given the apparently insurmountable legal difficulties involved. Even if it were possible to establish, it is difficult to imagine that an international bankruptcy court could have powers corresponding to national bankruptcy courts; with regards to creditors for example, 
to set aside existing contracts and to compel them to accept restructuring, and in terms of debtors, to seize collateral or to replace wayward governments (Eichengreen and Portes, 1995).

Moreover, some level of official involvement in the resolution of severe crises is necessary, given the problems associated with containing systemic risk (Group of Ten, 1996).

Secondly, it has been proposed that changes should be made in the provision of loan contracts and bond covenants to both private and official borrowers. Such changes could facilitate orderly crisis resolution by encouraging dialogue between debtors and creditors, and among creditors, and by preventing dissident investors from holding up the settlement (Eichengreen and Portes, 1995). Provisions in loan contracts and bond covenants would provide for the collective representation of debt holders; allow a majority of creditors to alter the terms of payment through qualified majority voting; and require sharing among creditors of assets received from the debtor (Group of Ten, 1996, p14).

The third proposal is that IMF-supported debt moratoria could form the basis of orderly crisis resolution in exceptional circumstances (Group of Ten, 1996, Wyplosz,1998, and Eichengreen and Portes, 1995). Eichengreen and Portes (1995) suggest that the IMF should undertake a signalling function, advising when a unilateral payment standstill would be justified. The IMF sanction would mean that a government which received approval for a standstill would not risk its future access to credit. Equally, it is argued, moral hazard would be limited because of the possibility that the IMF would not sanction a moratoria. The Group of Ten (1996) stressed that while a suspension of payments may be necessary in extreme cases, there should not be any formal mechanism for signalling IMF approval.

Objections to an IMF-supported suspension of payments are based on the moral hazard problem and on disapproval of interfering with the efficient operation of the market. It has been argued that such a proposal could distort incentives and lead to excessive borrowing. However, it seems 
unlikely that countries would take excessive risks because of the possibility of a debt moratoria given the extremely painful consequences for a country which experiences a crisis. Furthermore, as Wyplosz (1998) points out, a suspension of payments would reduce the moral hazard that encourages lending by financial institutions that expect to be bailed-out by an IMF-led rescue. Here, however, the danger would be that IMF-sanctioned moratoria might throw out the baby of capital flows to emerging markets in general with the bath water of more speculative or less sustainable flows (Griffith-Jones, 1996, 75).

There are also objections to debt moratoria based on the argument that the cost of capital could rise for all borrowers if they were used too often. Moreover, the issue of contagion implies that the involvement of the private sector in the resolution of the problems of one country could lead to capital outflows from other countries (Fischer, 1998, p16). Reportedly, the possibility of an IMF-supported orderly work-out in one Asian country was not adopted because of fears that the crisis could spread to other regions. Such fears may always be there and inhibit the use of IMFsanctioned payment standstills.

Despite the inherent difficulties, however, the international community is agreed that there is a need for new procedures for the resolution of crises in heavily indebted countries. The experience of the 1980s and 1990s has shown that, with the changes to the character of international financial markets, the existing mechanisms for crisis resolution are no longer adequate.

The principal benefit from the establishment of orderly work-out procedures would be that priority could be given to dealing with the domestic implications of a crisis, rather than to paying back investors and creditors. This would be of particular value in situations where the basic fundamentals of the country concerned are sound, and the problem is more one of illiquidity than insolvency. In such cases, as Wyplosz (1998) points out, the weakness is usually a structural problem, such as high debt or a weak banking system, which will take time to be corrected. For 
such corrections to be worked through, it is imperative that the economic environment be as stable as possible, for as Wyplosz argues:

Structural changes are easier and less costly when the economy is growing. It is essential therefore that the priority be given to preventing the economy from being severely hit by the crisis. (Wyplosz, 1998, p18)

\section{Conclusions}

The international community has been reflecting on lessons emerging from the Asian crisis and what steps need to be taken to improve crisis prevention and crisis management in the new globalised economy. The IMF has played a central role in these discussions, putting forward its proposals for strengthening 'the architecture of the international monetary system'. While there is a general consensus that the ideas being put forward by the IMF are valuable, many now believe that more far-reaching reforms to the international financial system are necessary.

In terms of crisis prevention, the key IMF proposals put forward are: improving the availability and transparency of information regarding economic data and policies to both the fund and the public, together with strengthening IMF surveillance; strengthening domestic financial systems, by improving regulation and supervision; and encouraging the orderly and properly sequenced liberalisation of capital flows. Part IIIA of this chapter examined these proposals and showed that while they represent necessary steps toward a stronger international financial system, they would not be sufficient to prevent future crises. Key problems areas, such as the irrational behaviour of market participants and the difficulties of implementing financial sector reform in emerging market countries, represent major obstacles. Furthermore, while more prudent capital account liberalisation in emerging market countries would undoubtedly be welcome, many now believe that these sometimes fragile economies need to be protected from the full force of international 
finance. This could be done by one or several measures that better regulate or tax short-term capital flows, nationally and/or internationally.

At a national level, there seems to be growing consensus that market-based measures to discourage excessive surges of short-term capital flows are desirable, as part of a package of measures of good management of capital flows, which clearly includes prudent monetary and fiscal policies, as well as a well supervised domestic financial system. The Chilean system of nonremunerated reserve requirements on inflows up to one year seem to work particularly well, even though they have some micro-economic costs.

Internationally, prudential regulation of short-term capital flows also may need to be improved, and completed, where gaps exist. In this context, two types of capital flows seem particularly relevant. One is short-term bank loans, whose regulation may need to be modified, as the current system provides strong regulatory incentives towards more short-term loans and less for longterm loans. Portfolio flows are at present totally unregulated by source countries, if they originated in non-bank institutions, like institutional investors.

Risk-weighted cash requirements for mutual funds in source countries - varying with macroeconomic evolution in developing countries - may be an appropriate way to smooth such flows, which will be beneficial for developing countries. An alternative mechanism - that would achieve a similar objective - is the creation of a guarantee institution, that for a fee would guarantee flows to emerging markets, up to a limit. Another idea worth considering is that of a very small international tax on all foreign exchange transactions (known as the Tobin tax), that would also help discourage short-term flows without having any major effect on desirable long-term flows.

Though top priority needs to be given to crises prevention, measures also need to be put in place to improve crises management. These are explored in section IV. They include improving 
existing mechanisms - led by the International Monetary Fund - for a lender of last resort. Improvements relate firstly to the necessary speed of such lending, given the incredible speed with which markets move; approval of shadow programmes before a crisis occurs, with loans activated as soon as one breaks out may be an attractive option. The scale of existing facilities and I.M.F. resources needs to be enlarged, given the large scale of private funds flowing through international markets. To enhance the scale of official facilities, the prospect of co-financing with the private sector - and particularly with private banks - needs to be explored.

Finally, the issue of appropriate conditionality attached to financial packages needs to be revised, so that the conditionality is best targeted to restoring market confidence, with minimum damage to growth in the countries.

Also there is now a general consensus among the international community that new ways need to be found to involve the private sector in crisis resolution in order to achieve equitable burden sharing with regard to the official sector, limit the problems of moral hazard and reduce the size of official financing required. Part IVB of this chapter outlined some of the proposals for orderly debt workouts currently being reviewed: the establishment of international bankruptcy procedures; changes in the provisions of loan contracts and bond covenants; and IMF-supported debt moratoria. Examination of the possible benefits and short-comings of these proposals suggests that despite the objections raised, international dialogue on these issues needs to be stepped up.

The policy debate in these areas needs to lead urgently to new policy measures and mechanisms, so as to avoid costly currency crises happening again and to manage them better if unfortunately they do happen. Given the complexity of the issues involved, the policy debate and actions needs to be under pinned by improved knowledge. 
Further work is required to understand better than we currently do:

a) How international capital and credit markets work. This will include for example, better understanding of how decisions are made by different categories of bankers, fund managers and other actors to enter and leave countries. What explains domestic investors behaviour? Are some foreign investors/lenders more volatile than others? What determines whether contagion from one country to others occurs? What explains the path of contagion?

b) What policy mechanisms could best be deployed nationally and internationally to prevent currency crises in developing countries? This would include more detailed study of measures outlined above, but could also include others, like self-regulatory mechanisms within the financial industry and changes to the incentive systems of fund managers. The costs and benefits of different mechanisms need to be carefully assessed, together with the complex issues of implementation.

c) Finally there is the question of which existing international institutions are best suited for carrying out the different tasks, and whether there are any institutional gaps to be filled? How can co-ordination - between international institutions and between them and national authorities - best be improved? How can co-ordination between international public and private institutions most fruitfully be improved? 


\section{References}

Agosin M. 1996 "El retorno de los capitales extranjeros a Chile” El Trimestre Economico, Mexico.

Akyuz Y. 1998. The East Asian Financial Crisis: Back to the Future?

http://www.unicc.org/unctad/en/pressref/prasia98.htm

d'Arista J and Griffith-Jones S. 1998. The Boom of Portfolio Flows to 'Emerging Markets' and its $\underline{\text { Regulatory Implications, }}$, mimeo IDS

Bagehot W. 1873 Lombard Street: A Description of the Money Market London. Reprinted John Murray, 1917.

Bank for International Settlements (BIS). 1995. 65th Annual Report (Basle, BIS)

Boorman J. 1998. Reflections on the Asian Crisis: Causes, Culprits, and Consequences, paper prepared for the FONDAD conference on 'Coping with financial crises in developing and transition countries: regulatory and supervisory challenges in a new era of global finance', March 1998

Budnevich C. and Le Fort G. 1997 "Capital account regulations and macro-economic policy: two Latin American experiences" Banco Central de Chile. March. Documento de Trabajo 06. Santiago, Chile. 
Camdessus M. 1998a. Is the Asian Crisis Over? Address by Michel Camdessus at the National Press Club, April 2 1988, Washington DC http://www.imf.org/external/np/speeches/1998/040298.HTM

Camdessus M. 1998b. Capital Account Liberalization and the Role of the Fund. Remarks by Michel Camdessus at the IMF Seminar on Capital Account Liberalization, March 9 1998, Washington DC http://www.imf.org/external/np/speeches/1998/030998.HTM

Chote R. 1998. 'Crystal Balls in Washington' in the Financial Times, April 17 1998, p19.

Corsetti, Giancarlo, Pesenti, Paolo, Roubini, Nouriel, 1998, 'What caused the Asian currency and financial crisis?', Asian Crisis Homepage, March 1998, http://www.stern.nyu.edu/ nroubini/asia/AsianCrisis.pdf

Eichengreen B and Portes R. 1995. Crisis? What Crisis? Orderly Workouts for Sovereign Debtors (London, CEPR)

Feldstein, Martin, 1998, 'Refocusing the IMF', Foreign Affairs, March/April 1998, Vol. 77, No. 2, pp 20-33

Ffrench-Davis R and Griffith-Jones S (eds). 1995. Surges in Capital Flows to Latin America (Boulder, Lynne Reinner)

Fischer, Stanley, 1997, 'Capital Account Liberalization and the Role of the IMF', 19 September 1997 , http://www.imf.org/external/np/apd/asia/FISCHER.htm 
Fischer S. 1998. 'The IMF and the Asian Crisis', March 20 1998, Los Angleles. http://www.imf.org/external/np/speeches/1998/032098.HTM

Greenspan, Alan, 1998, Financial Times, 28 February 1998

Griffith-Jones S. 1998 (forthcoming). Global Capital Flows. (London, MacMillan)

Griffith-Jones S. 1996. 'How can future currency crises be prevented or better managed?' in Jan Joost Teunissen (ed), Can Currency Crises Be Prevented or Better Managed? (The Hague, FONDAD).

Griffith-Jones S and Lipton M. 1987. 'International lender of last resort:are changes required?', in Z Ros and S Motamen (eds) International debt and central banking in the 1980s (London, Macmillan)

Group of Ten. 1996. The Resolution of Sovereign Liquidity Crises, A Report to the Ministers and Governors prepared under the auspices of the Deputies, May 1996.

IMF. 1998. Toward a Framework for Financial Stability, Prepared by a Staff Team led by David Folkerts-Landau and Carl-Johan Lindgren (Washington, International Monetary Fund).

IMF. 1997. World Economic Outlook: Interim Assessment, December 1997 (Washington, International Monetary Fund).

IMF 1995. International Capital Markets: Developments, Proespects and Key Policy Issues. Washington D.C. 
Interim Committee of the Board of Governors of the IMF. 1998. Communiqué, April 161998. http://www.imf.org/external/np/cm/1998/041698a.htm

Kaul I, Grunberg I, and U1 Haq M (eds). 1996. The Tobin Tax: Coping with Financial Volatility (New York, Oxford Univeristy Press)

Kenen P. 1996. 'The Feasibility of Taxing Foreign Exchange Transations', in The Tobin Tax: Coping with Financial Volatility (New York, Oxford Univeristy Press)

Keynes, John M., 1936, The General Theory of Employment, Interest and Money, (Cambridge University Press, Cambridge)

Khan M and Reinhart C. 1995. 'Macro-economic management in APEC economies; the response to capital flows', in M Khan and C Reinhart (eds) Capital Flows in the APEC region. Occasional paper 122, IMF, Washington DC, March

Mishkin, Frederik, 1996, 'Understanding financial crises: a developing country perspective', proceedings of the World Bank Annual Conference on Development Economics, pp 29-77

McKinnon R. 1991. The order of economic liberalisation: Financial control in the transition to a market economy, John Hopkins, University Press, Baltimore

Obstfeld M. 1995. International currency experience: new lessons and lessons relearned, Brookings Papers on Economic Activity, No 2, p119-220 
Phillips S. 1998. 'Risk weighted regulation'. Paper presented at FONDAD Conference.

Holland. March.

Radelet, Steven, Sachs, Jeffrey, 1998, 'The Onset of the East Asian Financial Crisis', $1^{\text {ST }}$ draft, 10 February 1998,

http://www.hiid.harvard.edu/pub/other/eaonset.pdf

Rodrik, Dani, 1998, 'Who Needs Capital Account Convertibility?', University of Harvard http://www.nber.org/ drodrik/essay.PDF

Soros, George, 1997, 'Avoiding a Breakdown', Financial Times,

31 December 1997, p 12

Stiglitz J. 1994. 'The role of the state in financial markets', Proceedings of the World Bank Annual Conference on Development Economics, IBRD, p19-61

Stiglitz, Joseph, 1997, 'Statement to the Meeting of Finance Ministers of ASEAN plus 6 with the IMF and the World Bank, Kuala Lumpur', 1 December 1997, http://www.worldbank.org/html/extdr/extme/jssp120197.htm

Stiglitz J. 1998a. 'Boats, planes and capital flows', personal view in the Financial Times, March 25 1998, p32

Stiglitz J. 1998b. The Role of International Financial Institutions in the Current Global Economy. Address to the Chicago Council on Foreign Relations, February 27 1998, Chicago. http://www.worldbank.org/html/extdr/extme/jssp022798.htm 
Strauss-Kahn D. 1998. 'A Fix, not a Fudge', personal view in the Financial Times, April 17, 1998

Wade R and Veneroso F. 1998. The Asian Financial Crisis: the Unrecognized Risk of the IMF's Asia Package, draft manuscript, Russell Sage Foundation, February 11998.

Wolf, Martin, 1998, 'Flows and Blows', Financial Times, 3 March 1998, p 22

World Bank. 1997. Private Capital Flows to Developing Countries (Washington DC, The World Bank)

Witteveen H. 1998. 'Economic Globalisation in a Broader, Long-term Perspective: Some Serious Concerns' in J.J. Teunissen (ed) The Policy Challenges of Global Financial Regulation. FONDAD. The Hague.

Wyplosz, C. 1998. Globalised Financial Markets and Financial Crises (London, CEPR) 